\title{
Experimental Study on the Force Characteristics of Superlong Pile Groups in Silty Sand
}

\author{
Yonghui Li $\left(\mathbb{D},{ }^{1}\right.$ Dinghao Zhang $\mathbb{D}^{1},{ }^{1}$ Yunlong Liu $\left(\mathbb{D},{ }^{1}\right.$ and Lujie Chen $\mathbb{D}^{2}$ \\ ${ }^{1}$ School of Civil Engineering, Zhengzhou University, Zhengzhou 450001, Henan, China \\ ${ }^{2}$ School of Resources and Safety Engineering, Central South University, Changsha 410083, Hunan, China \\ Correspondence should be addressed to Dinghao Zhang; dinghaozhang424@163.com
}

Received 10 November 2020; Revised 7 April 2021; Accepted 24 November 2021; Published 2 February 2022

Academic Editor: Luís C. Neves

Copyright (c) 2022 Yonghui Li et al. This is an open access article distributed under the Creative Commons Attribution License, which permits unrestricted use, distribution, and reproduction in any medium, provided the original work is properly cited.

Laboratory model testing of single pile and superlong pile groups in saturated silty sand was conducted to investigate the response and bearing behavior of superlong pile groups with a high or low cap under vertical loads. The load transfer mechanism and bearing behavior of the pile shaft were discussed in detail. The load-settlement curve of the loaded superlong pile groups belongs to the type of gradual descent in silty sand. The transferred load decreased along the pile length during loading, but the gradients differed in different positions of the superlong pile group foundation with a high or low cap. The maximum shaft friction of the superlong pile groups with a high and low cap is about 2.5 times and 1.8 times, respectively, than that of the single pile. In addition, the tip resistance of the piles in the pile group foundation is about 2-3.5 times that of the single pile. The friction resistance of the superlong pile group foundation with a low cap was slightly larger than that of the high cap in the entire pile length, and two peaks and one peak, respectively, were observed. Under the ultimate load, the pile-soil maximum relative displacement of the friction on the pile side in the silty sand stratum was about $3 \%$ of the pile diameter. Under the ultimate load, the load sharing ratio of the pile side resistance of the two types of pile group foundations was about $60 \%$ of the total load. The load sharing ratios at the pile tip of the superlong pile groups with high and low caps are $40 \%$ and $33 \%$. Furthermore, equations were proposed to determine the axial capacity of the superlong pile group based on the single pile bearing capacity and were applied to analyze the test pile. The calculated ultimate bearing capacity was similar to the measured value, with a maximum error of only $4.88 \%$, thus validating the proposed method.

\section{Introduction}

In engineering, a superlong pile group foundation refers to piles that exceed $50 \mathrm{~m}$ in length or have a ratio of length to diameter $(l / d)>50[1]$. A superlong pile group can provide higher bearing capacity, better settlement control, and significantly improved seismic behavior of a superstructure than a common pile group due to the long pile length. Due to rapid socioeconomic development, super-large and supertall buildings and long-span bridges have emerged; thus, superlong pile group foundations are increasingly used in engineering construction [2]. For example, the steel pipe piles used in the Shanghai World Financial Center and the Jinmao Tower are $80 \mathrm{~m}$ long. The bored piles used in 117 buildings in Tianjin are $120 \mathrm{~m}$ long, and the bored piles used in the sixth bridge of the Hangzhou Qiantang River are $130 \mathrm{~m}$ long. However, the theoretical research on super-long pile group foundations still lags far behind engineering practice, and the load transfer characteristics, including the load proportion of the pile and soil, the skin friction distribution, the evolution of the tip resistance, as well as calculation methods of the bearing capacity, remain scientific problems to be solved.

In recent years, numerous domestic and international scholars have conducted extensive research on the load transfer mechanism of superlong piles using large-scale models and field-testing techniques to solve these problems. The research has shown the following results [3-9]. (1) The load of a superlong pile is mainly borne by the skin friction resistance of the pile under a vertical load, and the resistance 
occurs from top to bottom; this is referred to as a pure friction pile. (2) The skin friction resistance and tip resistance are asynchronous and are coupled. (3) Shaft resistance softening occurs under the ultimate load in the upper part of the pile body. (4) The difference in soil properties results in different forms of pile skin friction. These results apply primarily to superlong single piles. In practical projects, especially in super high-rise buildings, superlong piles are mostly used in the form of pile groups. However, relatively little work has been performed to research superlong pile groups. Yao [10] found that the vertical load carried by the cap in a pile group-soil-cap system constituted a small part of the total applied vertical load. However, the presence of the pile cap caused the crushing of the soil between the piles, complicating the pile-soil interaction in a three-dimensional nonlinear numerical model. Therefore, the finite element model did not reflect the nonlinear characteristics of the pile-cap-soil interaction and did not consider the sequence of mobilization of the pile shaft skin friction and tip resistance was substantially different under vertical load [11]. Wang et al. [12] and Zhou and Kuang [13] carried out largescale model tests. The results showed that the ultimate bearing capacity of each pile in the super-long group pile foundation with a high cap in soft and clay soil foundation was lower than that of the single pile, and the skin friction resistance of the foundation pile increased gradually along the pile body. The resistance reached the maximum near the end of the pile, unlike in the single pile. More recently, Li et al. [14] observed that the ultimate bearing capacity of each pile in the superlong group pile foundation was larger than that of a single pile in a loess foundation. Due to the influence of the cap, the resistance at the end of the pile caused the axial force to decrease sharply near the end of the pile. An analysis indicated that the load transfer response was different from that of the pile without the pile caps due to the influence of the pile caps. In addition, the soil properties and number of piles had a considerable influence. Fattah et al. [15] investigate the behavior of piled raft system in different types of sandy soil. It is found that the piles work as settlement reducers effectively when the number of piles is greater than 6 than when the number of piles is less than 6 . The settlement can be increased by about 8 times in $(1 \times 2)$ free standing pile group compared with the piled raft of the same size. The effect of piled raft in reducing the settlement vanishes when the number of piles exceeds 6. Al-Omari et al. [16] investigated the load transfer in pile groups constructed in saturated and unsaturated soil using aluminum model piles with six group configurations in addition to pullout test. Results of ultimate load capacity obtained from the load-displacement curves revealed an increase in the ultimate load with increasing the number of piles in the group for the same soil properties and an increase in pile capacity when the soil becomes in unsaturated state compared with saturated soil for the same pile group tested. Further, Fattah et al. [17] investigated the influence of matric suction on the behavior of single pile and pile group and the amount of increase in the bearing capacity due to the influence of this suction. The results showed that the sharing of load between shaft and end resistance for single pile in saturated soil is halved when the pile reaches its ultimate resistance, while this response is different for unsaturated soil where the load is transferred as a whole to the pile tip at approximately the intermediate stages of loading according to the analysis criteria adopted. Moreover, recent studies did not consider the specification of the pile group effect of the pile length, pile diameter, soil properties, and cap [18]. Therefore, it is necessary to analyze the load transfer characteristics of superlong pile groups with a high or low cap and derive the equations of the bearing capacity of superlong pile groups in a silty sand foundation.

In order to have a deeper knowledge of the load transfer mechanism of superlong pile groups and propose more suitable design and calculation methods, a series of laboratory loading testing was first designed and finished on superlong pile groups in typical saturated silty sand of Zhengzhou in China. The effects of a high or low cap on the load-settlement relationship of superlong pile groups, the distribution of lateral friction, the load-sharing ratio of the soil under the cap, the load distribution between the piles, and the difference in settlement between piles are analyzed using indoor model tests. According to the pile axial force, pile side friction, and interpile earth pressure obtained from the test results, the hypothetical condition of stress superposition is modified based on the Geddes theory, and a calculation method of the bearing capacity of a superlong pile group is proposed. The results provide a reference for improving the calculation method of the bearing capacity of a superlong pile group foundation and the optimal design of the pile foundation.

\section{Laboratory-Based Superlong Pile Group Load Test}

2.1. Test Items. The test was conducted using the self-developed model box system illustrated in Figure 1(a). One side was a removable wall to facilitate the filling and removal of the test soil. The model box was placed in the pit, and the body was $1.5 \mathrm{~m}$ below the ground. The geometric similarity ratio was $1: 20$ to meet the measurement accuracy requirements and test equipment limitations.

Loading tests (named CT1 and CT2) of 25 pile groups were conducted in this project. The tests involved two superlong single piles, a $5 * 5$ high-cap pile foundation (HCPF) and a $5 * 5$ low-cap pile foundation (LCPF), as shown in Table 1 . The cap at the top of the pile consisted of a steel plate with a size of $900 \mathrm{~mm} * 900 \mathrm{~mm} * 50 \mathrm{~mm}$. The distance between the pile groups was $175 \mathrm{~mm}(3.5 \mathrm{D})$, and the distance from the pile center to the edge of the raft was $100 \mathrm{~mm}(2.0 \mathrm{D})$. The distances of all piles to the sample container $(650 \mathrm{~mm})$ were greater than 10 times the pile diameter $(50 \mathrm{~mm})$ to eliminate the boundary effect [19-21]. The plan arrangement of the piles is shown in Figure 1(b). Model piles were prepared from plexiglass pipes with an outer diameter of $50 \mathrm{~mm}$ and a thickness of $5 \mathrm{~mm}$, with an elastic modulus of $3.48 \mathrm{GPa}$, which was verified in a mechanical test. The plexiglass surface was evenly coated with a layer of epoxy resin and a low-molecular compound to increase its roughness to simulate the contact characteristics 


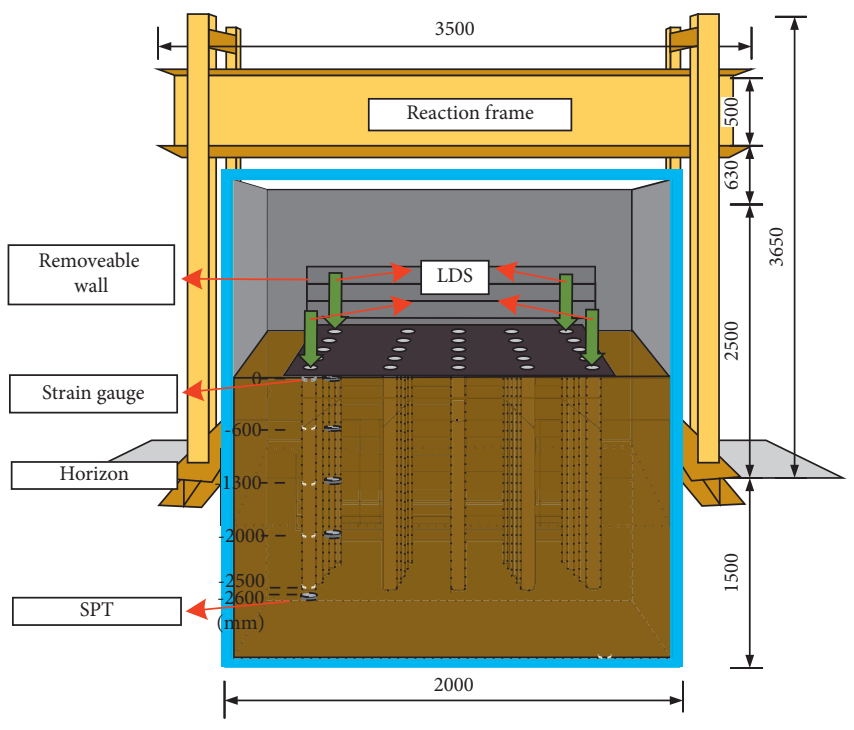

(a)

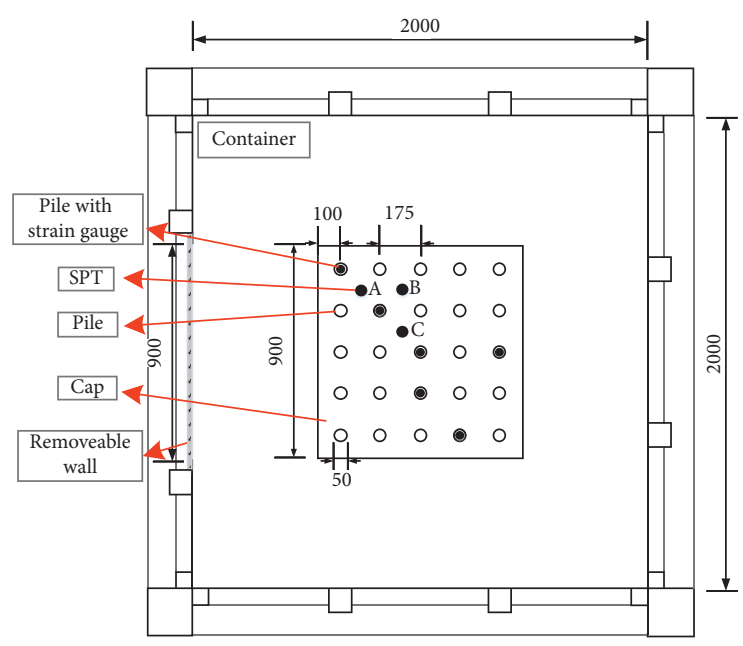

(b)

FIGURE 1: Model box system (mm). (a) Model box (strain gauges on the surface of the pile, soil pressure transducers (SPTs) among piles and laser displacement sensors (LDSs) on the cap). (b) Installation plan of model box and sensor configuration.

TABle 1: Parameters of the model tests.

\begin{tabular}{|c|c|c|c|c|c|c|c|}
\hline Test item & $\begin{array}{c}\text { Pile diameter } D \\
(\mathrm{~mm})\end{array}$ & $\begin{array}{l}\text { Pile length } L \\
(\mathrm{~mm})\end{array}$ & $\begin{array}{c}\text { Buried depth } H \\
(\mathrm{~mm})\end{array}$ & $\begin{array}{c}\text { Aspect ratio } D / \\
L \\
\end{array}$ & $\begin{array}{c}\text { Pile } \\
\text { spacing }\end{array}$ & $\begin{array}{c}\text { Number of } \\
\text { piles }\end{array}$ & Raft size $(\mathrm{mm})$ \\
\hline $\begin{array}{l}\text { Single-pile } \\
\text { A }\end{array}$ & 50 & 2500 & 2500 & 50 & - & 1 & - \\
\hline $\begin{array}{l}\text { Single-pile } \\
\mathrm{B}\end{array}$ & 50 & 2500 & 2500 & 50 & - & 1 & - \\
\hline $\mathrm{HCPF}$ & 50 & 2800 & 2500 & 50 & $3.5 \mathrm{D}$ & 25 & $900 * 900 * 50$ \\
\hline $\mathrm{LCPF}$ & 50 & 2500 & 2500 & 50 & $3.5 D$ & 25 & $900 * 900 * 50$ \\
\hline
\end{tabular}

between the surface of the bored piles and the soil. It is known that the contact characteristics have a negligible effect on the measurement accuracy of the bending moment [18].

2.2. Sensor Configuration. Pressure cells were installed under the caps of the 25 pile groups. Ten BX120-5AA resistance strain foil gauges were installed along the pile's length; 2 gauges were placed in each of the 5 sections. Four laser displacement sensors (LDSs) were installed in the four corners of the loading plate to measure the settlement of the cap. The average value obtained from the four displacement sensors was used as the settlement value of the cap. The SPT, strain gauges, and the LDS configuration are shown in Figure 1.

2.3. Geological Conditions of the Test. The saturated silty sand used in this test was acquired from the Economic Development District in Zhengzhou, China. The particle size distribution curve of the soil is shown in Figure 2. Each layer of soil was $100 \mathrm{~mm}$ thick and was then rammed to a thickness of $80 \mathrm{~mm}$. Before the start of the loading test, the foundation soil has to be immersed in water so that the foundation soil is saturated. Geotechnical tests were carried out on each layer of soil; the average values are shown in Table 2.

2.4. Test Process. The test was conducted to determine the load transfer mechanism of the superlong pile groups under a vertical load. After the model pile had been constructed, determine the burying position of the model pile and lay out in the model slot. Then, the foundation soil was placed into the model layer by layer (about $10 \mathrm{~cm}$ for each layer). The outline of the model during and after filling is shown in Figure 3.

Compressive multistage loading tests were conducted. As shown in Table 3, there were 10, 14, and 8 loading stages for the HCPF, LCPF, and the single pile foundation, with the first loading of $20 \mathrm{kN}, 10 \mathrm{kN}$, and $0.5 \mathrm{kN}$, respectively. The number of unloading stages was half that of the loading stages, and the decrement load was twice the increment load. During each loading stage, the vertical settlement was recorded at time intervals of 5, 10, 30, and $60 \mathrm{~min}$. For the unloading stages, the time interval was $60 \mathrm{~min}$. In addition, if the unequal settlement value was less than $0.1 \mathrm{~mm}$ during the loading stages, the condition was considered to be stable. When the difference value of $0.1 \mathrm{~mm}$ occurred twice, the test was considered stable, and the next load was applied. 


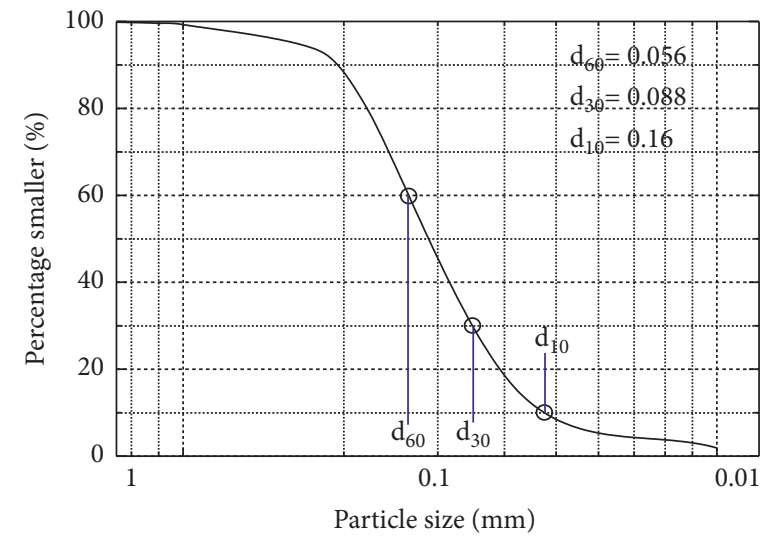

FIgURE 2: Particle size distribution curve of the foundation soil.

TABLe 2: Basic physical and mechanical parameters of the foundation soil.

\begin{tabular}{|c|c|c|c|c|c|c|c|c|}
\hline $\begin{array}{l}\text { Specific } \\
\text { gravity } G_{\mathrm{s}}\end{array}$ & $\begin{array}{c}\text { Density } \rho \\
\left(\mathrm{g} / \mathrm{cm}^{3}\right)\end{array}$ & $\begin{array}{c}\text { Water } \\
\text { content } \omega \\
(\%)\end{array}$ & $\begin{array}{c}\text { Compression } \\
\text { coefficient } \alpha_{\mathrm{v}} \\
\left(\mathrm{MPa}^{-1}\right)\end{array}$ & $\begin{array}{l}\text { Oedometric } \\
\text { modulus } E_{\mathrm{s}} \\
(\mathrm{MPa})\end{array}$ & $\begin{array}{c}\text { Cohesion } c^{\prime} \\
(\mathrm{kPa})\end{array}$ & $\begin{array}{c}\text { Friction } \\
\text { angle } \varphi^{\prime}\left({ }^{\circ}\right)\end{array}$ & $\begin{array}{c}\text { Curvature } \\
\text { coefficient } \mathrm{Cu}\end{array}$ & $\begin{array}{l}\text { Nonuniform } \\
\text { coefficient } C c\end{array}$ \\
\hline 2.69 & 1.95 & 26.8 & 0.15 & 10.3 & 8.8 & 31.2 & 2.857 & 0.864 \\
\hline
\end{tabular}

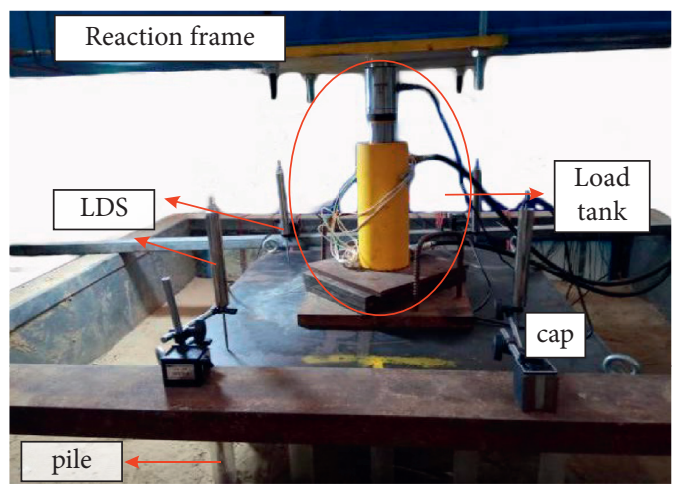

(a)

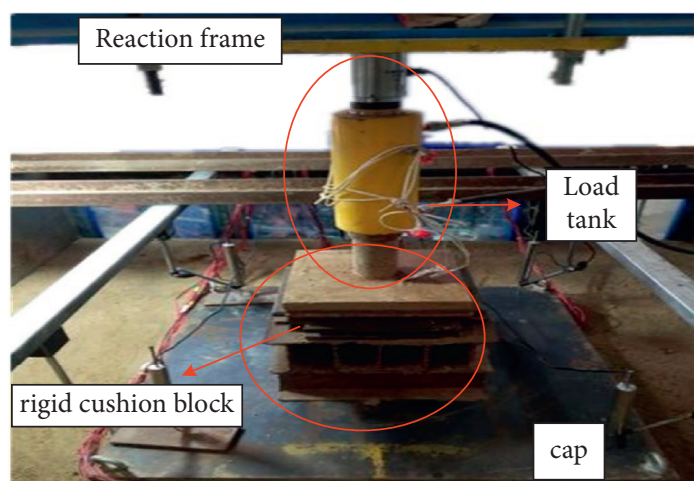

(b)

Figure 3: Installation process of the test models: (a) the photo of HCPF; (b) the photo of LCPF.

TABLE 3: Information of the test process.

\begin{tabular}{lccccc}
\hline Pile type & Loading stage & Unloading stage & First load $(\mathrm{kN})$ & Increment $(\mathrm{kN})$ & Decrement $(\mathrm{kN})$ \\
\hline HCPF & 10 & 5 & 20 & 20 & 40 \\
LCPF & 14 & 7 & 10 & 20 & 40 \\
Single pile & 8 & 4 & 0.5 & 0.5 & 1 \\
\hline
\end{tabular}

\section{Result and Discussion}

3.1. Load-Settlement Curves. The Q-S curve of the superlong pile group (HCPF and LCPF) loading test (Figure $4(\mathrm{a})$ ) is a smooth curve. After the maximum load of $200 \mathrm{kN}$ was applied to the HCPF, the settlement did not converge. Thus, the previous-stage load $(180 \mathrm{kN})$ was used as the ultimate bearing capacity, and the maximum settlement of the foundation was $33.53 \mathrm{~mm}$. The bearing capacity of the LCPF was $250 \mathrm{kN}$, and the foundation settlement was $33.82 \mathrm{~mm}$. The bearing capacity of the LCPF was substantially higher than that of the HCPF. The rate of decrease of load-settlement curve of the LCPF was lower than that of the HCPF, and the difference in the settlement between the foundations increased with an increase in the load. This result indicated that superlong pile group can provide higher bearing 


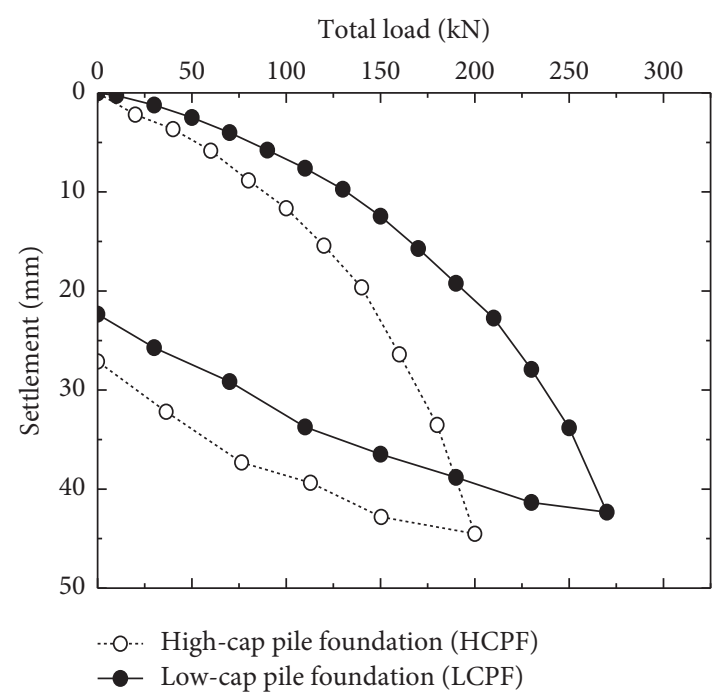

(a)

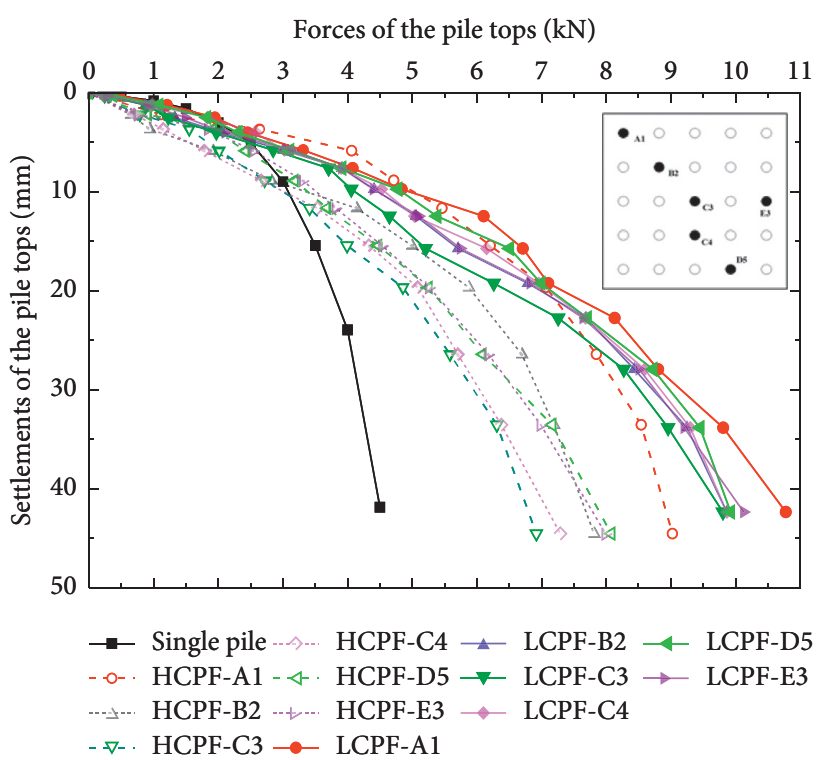

(b)

Figure 4: (a) The load settlement curves of the superlong pile foundation model tests. (b) The force settlement curves of the pile tops of the superlong pile foundations.

capacity, better settlement control, and significantly improved seismic behavior of a superstructure than a common pile group due to the long pile length. The present results are slightly different from the findings of Al-Omari et al. [16] who showed that the settlement increases with the applied load until the load reaches some critical point at the start of load application, and then the curve of the load-displacement becomes steeper, and after this point, the settlement increases with almost constant load.

The force settlement curves of the foundation piles in different position for different top loads are shown in Figure 4(b). In the initial stage of loading, the deformation of the HCPF and LCPF was larger than that of the single pile. As the load increased, the deformation of the foundation pile increased more slowly than that of the single pile. When the ultimate bearing state was reached, each foundation pile showed a significant increase in the bearing capacity, and piles in LCPF showed the largest increase. In addition, the load borne by the foundation pile of the LCPF was significantly higher than that of the HCPF, and its settlement deformation was smaller under the same load.

3.2. The Soil Resistance Distribution under the Cap. The soil stress between the piles at different buried depths and different loads for the LCPF and HCPF is shown in Figures 5 and 6 , respectively. In the initial stage of loading, the increase in the soil stress between the piles of the LCPF is small, showing a sharp decreasing distribution law along the buried depth. With the increase in the load, the soil stress between piles under the cap increases rapidly. At deeper depths, the rate of increase of the soil stress between the piles is relatively low. The soil stress along the buried depth decreases sharply at first and then increases slowly. The lowest soil stress between the piles occurs in the upper buried depth of the pile body. As the load reaches the ultimate bearing capacity of the pile group foundation, the rate of increase of the soil stress between the piles at each buried depth tends to decrease. Under the cap, the soil stress between the piles tends to be stable. The closer to the center of the cap, the smaller the soil stress between the piles in upper buried depth, the greater the soil stress is between the piles at the deeper depths (Figure 5). The high value of the pile cap group foundation (as shown in Figure 6) is different from that of the low cap pile group foundation. With the increase in the load, the soil stress $(50 \mathrm{~cm} \sim 200 \mathrm{~cm}$ ) between the piles decreases and then increases.

3.3. The Load Sharing Ratio of the Pile and Soil. The pile friction resistance, pile tip resistance, and soil reaction force (low cap) under the pile cap of the group pile foundation for different loads are shown in Figure 7. The load shared by the pile shaft and tip of the group pile foundation increases approximately linearly during early loading. Subsequently, it reaches the bearing limit under a small load level and then stabilizes. Under the same load condition, the pile shaft resistance of the HCPF is the same as that of the LCPF, whereas the pile tip resistance of the HCPF is considerably higher than that of the LCPF. These results show that the load transferred to the pile shaft is the same for the two types of pile group foundation, but the load transferred from the pile cap to the pile tip in the LCPF is relatively small. In addition, when loading to the ultimate bearing capacity, the load transferred to the pile tip of the LCPF is slightly higher than that of the HCPF, indicating that the bearing capacity of the pile tip is increased.

Figure 8 shows the load sharing ratios of different parts of the two types of pile group foundations (pile side friction resistance, pile tip resistance, and foundation soil reaction 


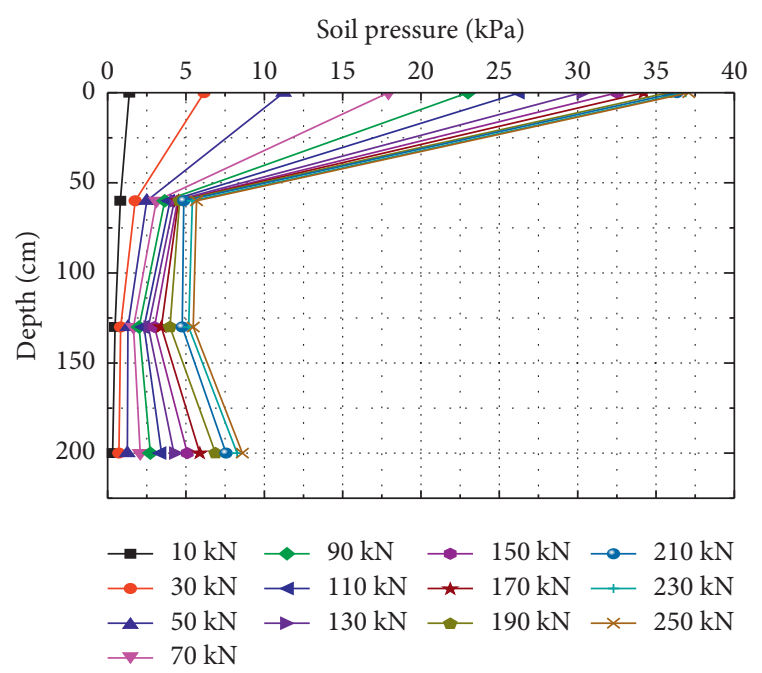

(a)

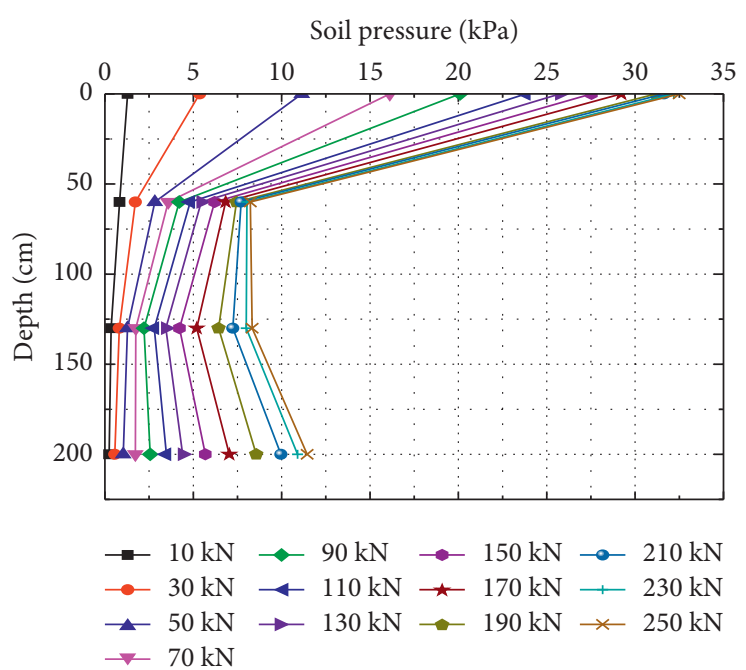

(b)

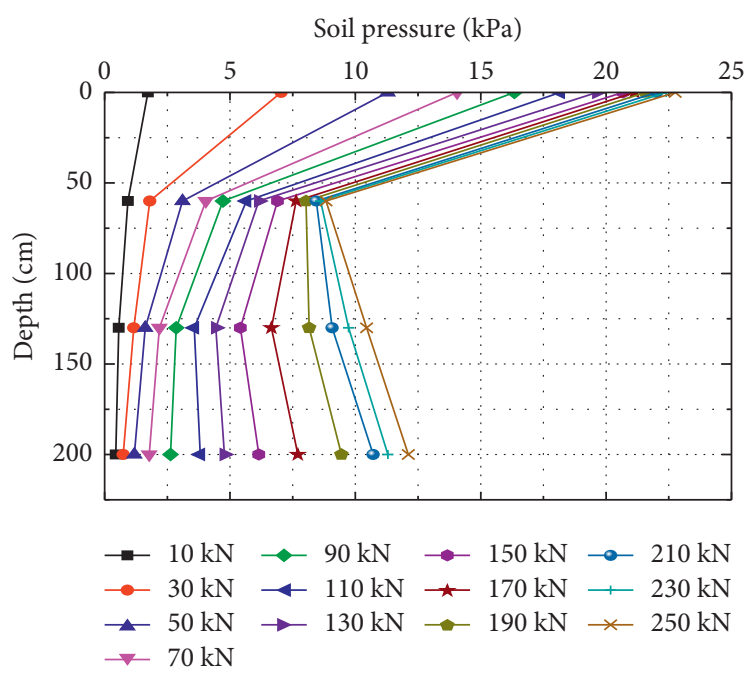

(c)

Figure 5: The soil stresses between the piles at different buried depths of the LCPF. (a-c) Different positions of SPT as shown in Figure 1(b).

force under the cap (low cap)) to the total load versus the foundation settlement. In the initial stage of loading, the pile shaft resistance of the two types of pile group foundations is relatively large and then decreases rapidly to about $60 \%$. The bearing capacity ratio of the pile end of the HCPF is considerably higher than that of the LCPF. As the foundation settlement increases, the ratio increases rapidly to a stable value (about 40\%). The pile tip bearing capacity of the LCPF increases faster than that of the HCPF in the initial stage of loading and then slowly increases to $33 \%$ under the ultimate load. The load sharing ratio of the foundation soil under the cap of the LCPF increases linearly at the beginning of loading and stabilizes at about 15\% after reaching its bearing limit. Subsequently, the load sharing ratio of the foundation soil shows a gradual downward trend and finally stabilizes at about $7 \%$. In a single pile, at the start of load applying, the percentage of distributed load is $82 \%$ for shaft and $18 \%$ for tip; then as the applied load increases, an increase in shaft and tip capacity is noticed until the pile reaches the failure point; and at this point, the transferred load is approximately quartered between the tip and shaft as indicated. This result indicated that the stress of the foundation soil under the cap plate significantly enhanced the bearing capacity of the foundation pile, but the load transferred to the pile shaft decreases from superlong single pile to superlong pile groups. The present results are inconsistent with the findings of Fattah et al. [17] who showed that the load transferred to the pile shaft increases as the number of piles increases for groups of piles tested. In addition, at the same settlement value, the friction resistance of the HCPF is the same as that of the LCPF, whereas the pile tip resistance of the HCPF is significantly higher than that of the LCPF.

The curves reflect the load transfer response of the two types of superlong pile groups. The analyses show that the response of the HCPF depends on the pile-soil interaction under vertical loads, whereas in the LCPF, the pile-soil-cap interaction bears most of the load. Due to the pile body compression of the foundation piles, the deformation of the 

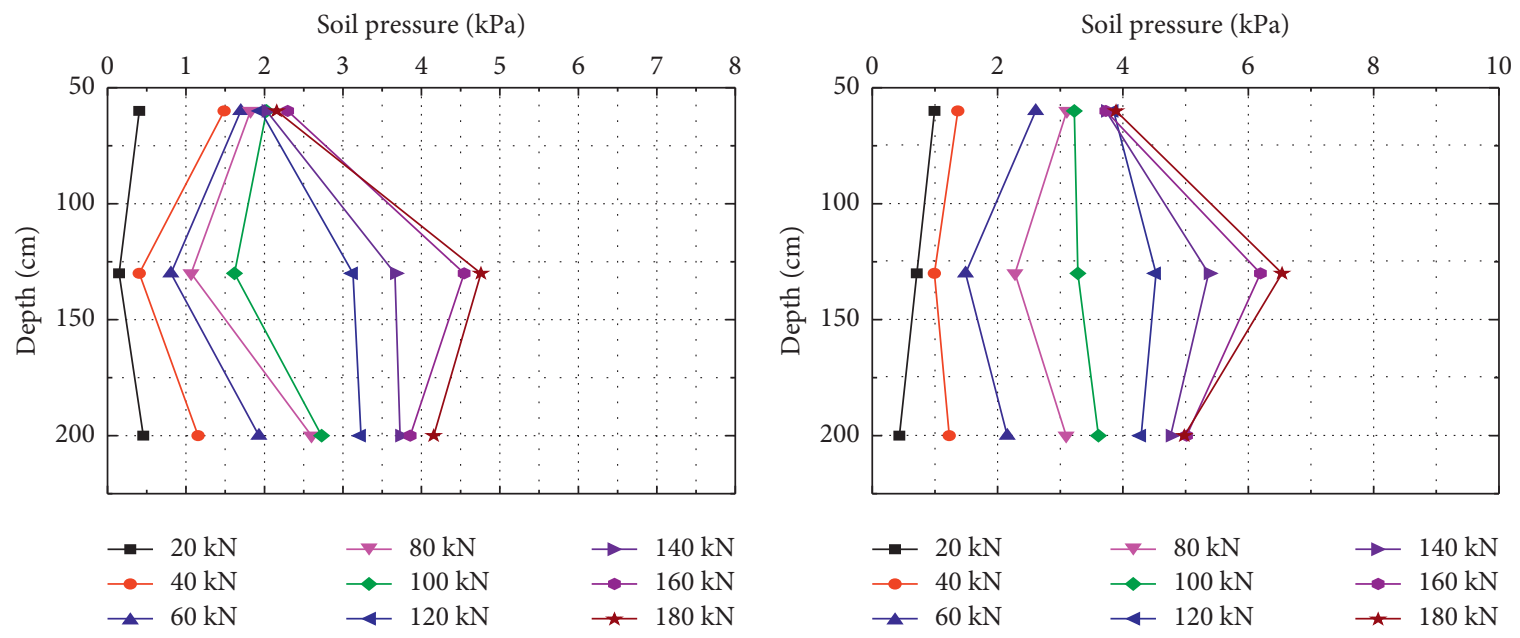

(a)

(b)

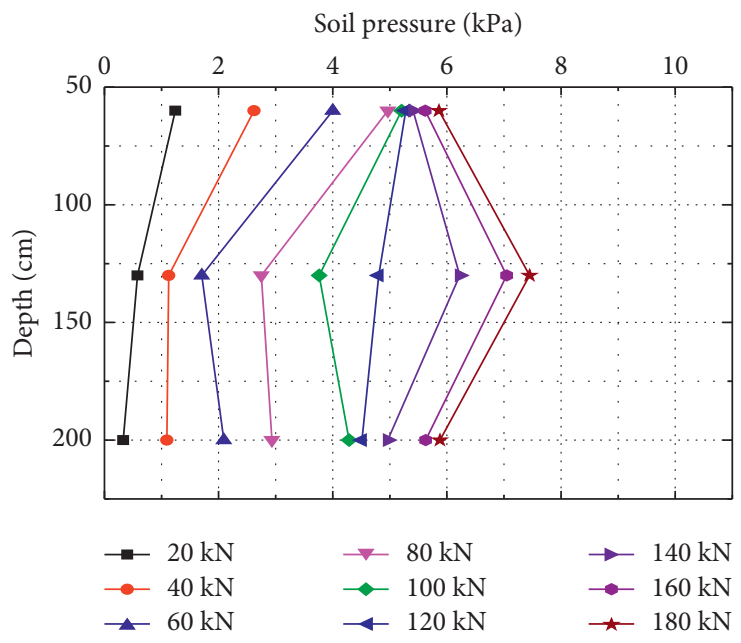

(c)

FIGURE 6: The soil stresses between the piles at different buried depths of the HCPF. (a-c) Different positions of SPT as shown in Figure 1(b).

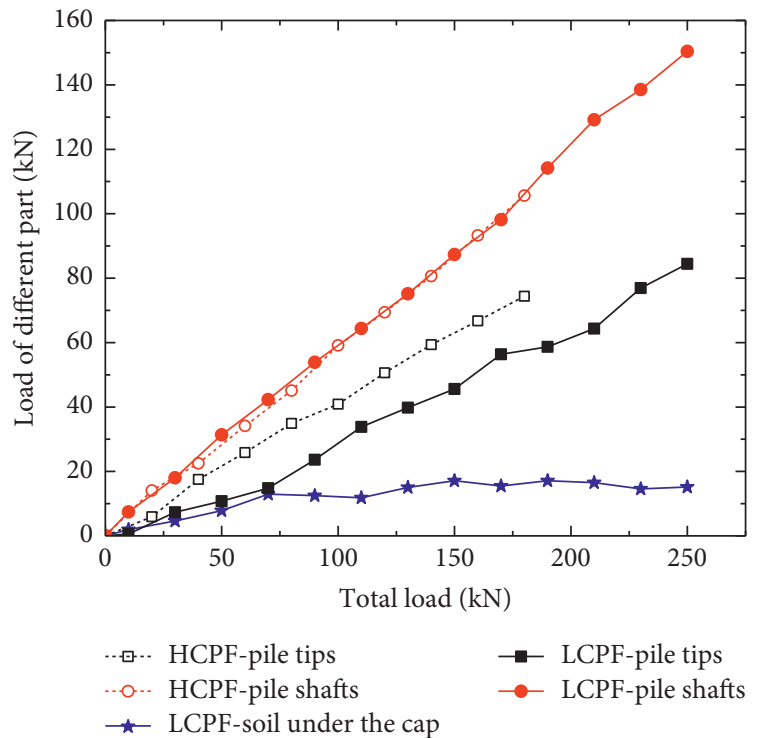

Figure 7: Variation curves of the load of different parts of the pile foundation with its total load.

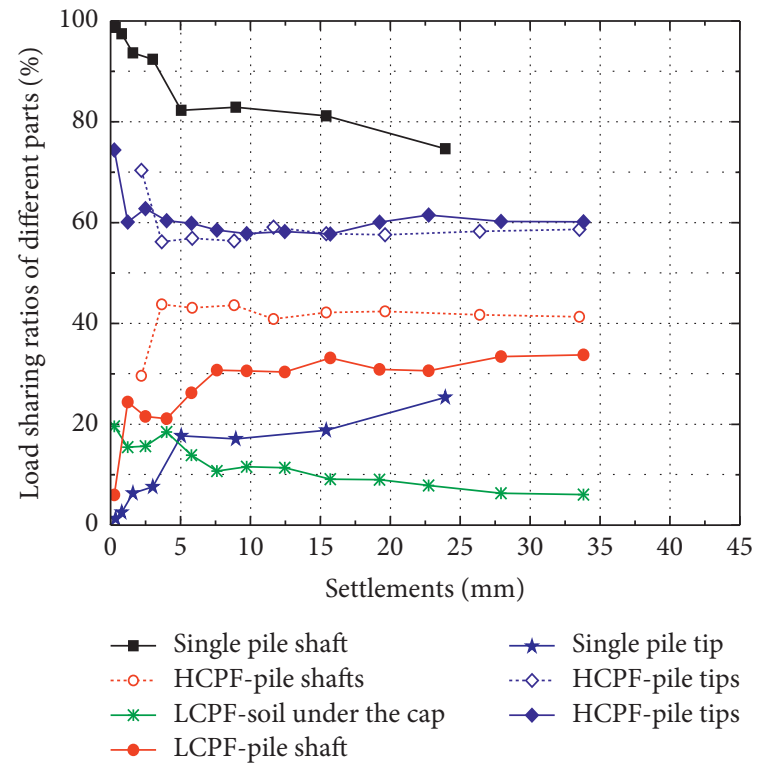

FIgURE 8: The load sharing ratios of different parts of the foundation versus the settlement. 
pile group foundation is relatively small at the beginning of loading. At this time, the foundation load is borne mainly by the pile friction resistance, and the amount of load transfer to the pile tip is relatively small. As the load increases, the pile tip resistance is also embodied progressively, and the pile side friction continues to increase. The pile tip bearing ratio of the pile group foundation (especially that of the LCPF) is significantly higher than that of the single pile (Figure 8). The reason is the silty sand [22]. In the LCPF, the compression deformation of the foundation soil first increases due to an increase in the vertical load on the foundation soil. Due to the lateral shear action of the foundation pile, the foundation soil under the cap is then deformed and stabilizes at a fixed value. Furthermore, the force and deformation of the foundation soil under the cap increase the friction resistance of the pile, thereby decreasing the load-bearing ratio of the foundation soil under the cap as the load increases.

\subsection{Load Transfer Mechanism}

3.4.1. Axial Stress. Figure 9 displays the axial force of the foundation pile of the pile groups and the single pile at different positions under the ultimate load. The axial force distribution is similar for the two types of superlong pile group foundations. The axial force of piles is lower where closer to the center, indicating that the load transfer modes of the two kinds of pile groups are similar. Compared with the LCPF, there is a significant difference in the axial force of the pile body at different positions of the HCPF. This result demonstrates that the force of each foundation pile is more uniform in the LCPF than the HCPF. In addition, the axial force distribution of the pile groups is different from that of the single pile, especially in the upper part of the pile. This response indicates that the pile group exhibits a higher bearing capacity and a better load transfer behavior than the single pile because more of the load is transferred to the pile tip.

3.4.2. Lateral Friction Resistance. The lateral friction resistance depends on the relative displacement between the piles and the soil, the stiffness ratio of the piles and soil, the lateral force on the pile shaft, and the soil properties. As shown in Figure 10, the shaft friction resistance of the HCPF exhibits a single peak, with the maximum value at half of the pile length, whereas that of the LCPF is similar to that of the single pile, with the maximum value at $1 / 4$ of the pile length; the curve has an " $M$ " shape. Moreover, the lowest friction values of the pile are observed near the center pile of the pile groups. The shaft friction resistance of the HCPF is lower than that of the single pile from pile top to the $1 / 4$ of pile length under the ultimate bearing capacity. In contrast, the shaft friction of the HCPF is about 2.5 times that of the single pile at half of the pile length. In addition, the shaft friction resistance of the LCPF is more than 1.8 times that of the single pile, and the difference between them reaches the maximum at a 1/4 the length above the pile shaft.
Therefore, for both the LCPF and HCPF, the soil between the piles in restrained condition when the pile distance equals $3.5 \mathrm{D}$ causes an increase in the normal stress on the side of the pile; thus, the pile friction resistance of the pile groups is higher than that of the single pile. In addition, during the shear interaction of the pilesoil transmitted along the soil side of the pile, it causes large shear deformation of the soil on the lower side of the foundation pile. Hence, the relative displacements of the pile and soil and the pile side friction resistance are relatively low from half of the pile length to the pile tip, resulting in the "M-shaped" curve.

The relationship between the pile shaft friction resistance and the pile-soil relative displacement at different depths is shown in Figure 11. For experimental purposes, the pile-soil relative displacement between the soil and pile layer $i, \Delta S_{i}$, can be expressed as

$$
\Delta S_{i}=S_{t}-\sum_{j=1}^{i} \frac{L_{j}}{2}\left(\varepsilon_{j}+\varepsilon_{j+1}\right),
$$

where $S_{t}$ is the pile head settlement, which can be measured by a displacement sensor at the top of the pile; $\varepsilon_{j}$ and $\varepsilon_{j+1}$ are the strain of the foundation piles at section $j$ and $j+1$, which can be measured by a strain gauge on the pile shaft; and $L_{j}$ is the length of the pile layer $i$.

The pile friction resistance increases rapidly when the relative displacement between the piles and the soil is small in the initial loading stage. The pile side friction resistance reaches the limit with the increase in the relative displacement between the piles and the soil. Subsequently, the average friction resistance increases slightly and then remains constant. The pile-soil relative displacement, which can play the ultimate shaft capacity, is, on average, $3 \%$ of the pile diameter in silty sand.

3.4.3. Tip Resistance. Figure 12 shows the pile tip resistance versus the pile tip settlement of the pile groups and single pile at different positions. At higher pile tip settlement values, the tip resistances of the foundation piles in the superlong pile groups are greater than that of the single pile, and the differences become more significant as the pile tip settlement increases. Under the ultimate load, the tip resistance of the piles in the pile group foundation is about 2-3.5 times that of the single pile (the resistance is largrs for the corner pile, followed by the side piles and the center pile). The rate of change of the pile tip resistance is larger for the HCPF than for the LCPF at different positions. The reason is that the upper load of the HCPF is transferred to the pile tip only through the pile body, resulting in a concentrated load. In contrast, in the LCPF, the load is transferred to the tip of the pile by the soil and piles, thereby distributing the load. Moreover, as the tip displacement increases, the pile tip resistance of the HCPF tends to be relatively stable, whereas that of the LCPF shows an increasing trend under the ultimate load. The final load and the ultimate pile tip resistance are higher for the LCPF than for the HCPF. 


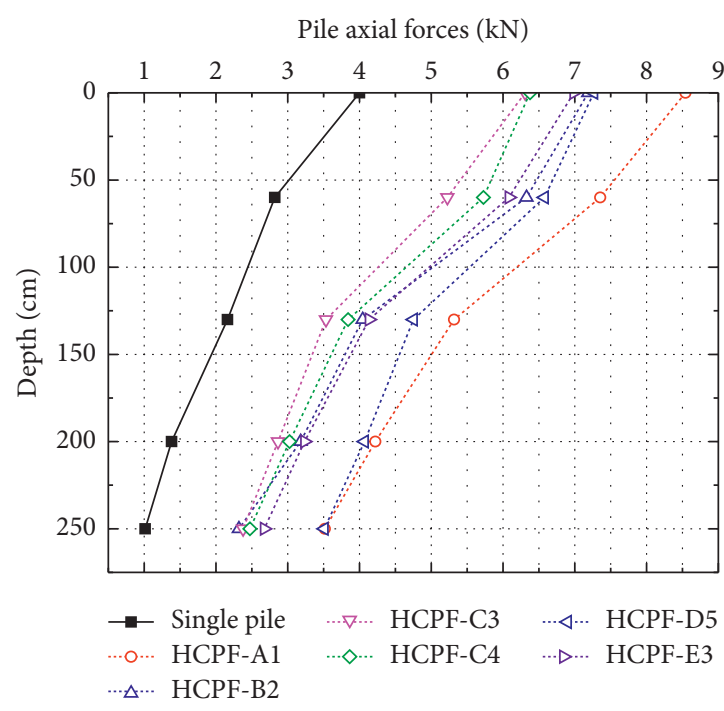

(a)

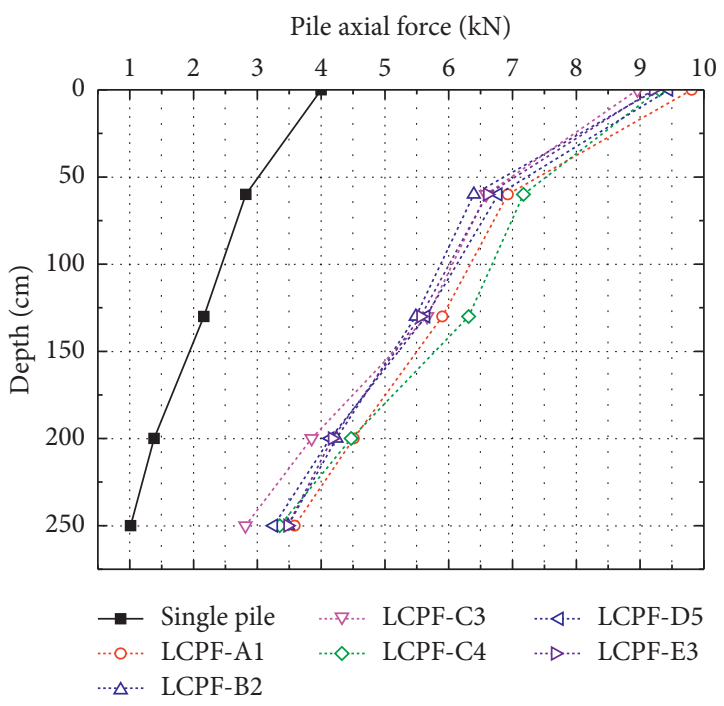

(b)

FIGURE 9: The axial forces of the pile groups and the single pile under the ultimate bearing capacity. (a) HCPF piles and single pile. (b) LCPF piles and single pile.

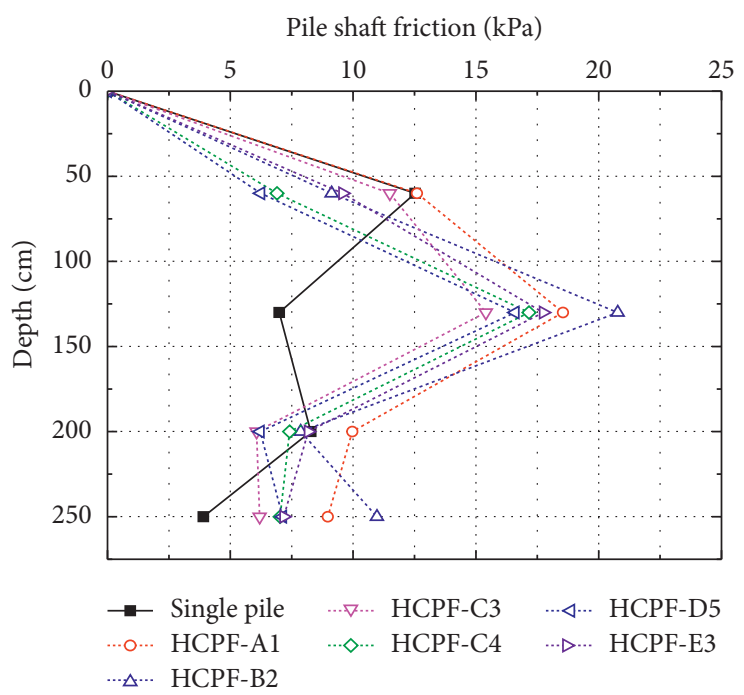

(a)

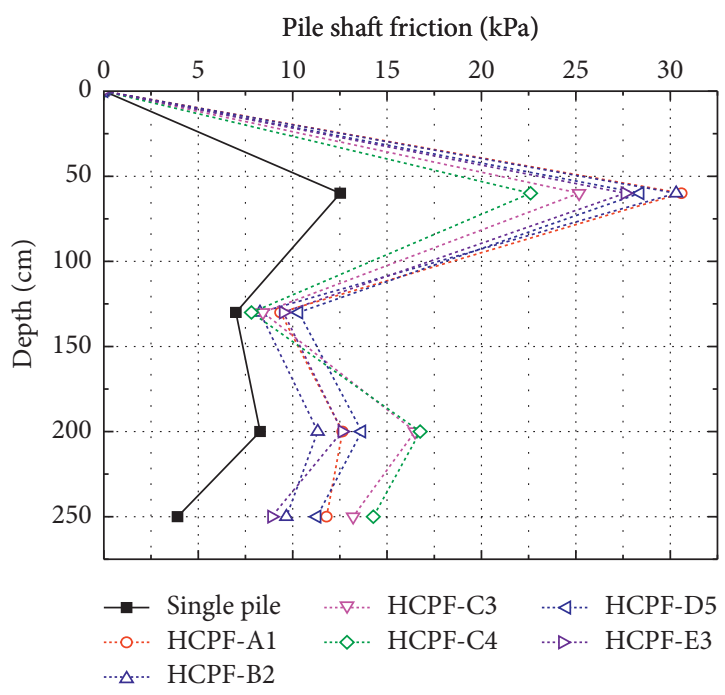

(b)

FIGURE 10: Pile shaft friction resistance of the foundation piles and the single pile under the ultimate bearing capacity. (a) HCPF piles and single pile. (b) LCPF piles and single pile.

\section{Proposed Method to Calculate the Ultimate Bearing Capacity of Superlong Pile Groups}

The results of existing research $[23,24]$ and this study indicate that, based on the assumptions of the Geddes theory [25], the lateral shear distribution of the superlong pile groups in silty sand should be a triangular distribution, which is slightly different from the assumption of stress superposition. Therefore, in this study, the assumptions of the conditions of the stress superposition for the superlong pile group foundation are modified. Thus, we propose an equation to calculate the ultimate bearing capacity of superlong pile groups using the subentry (pile tip resistance, shaft friction resistance, and cap resistance) efficiency factors of the pile groups of the cap-pile-soil interaction.

4.1. Equation to Calculate the Ultimate Bearing Capacity of Pile Groups. We propose the following equation to calculate the ultimate bearing capacity of superlong pile groups. It considers the influence of the pile length, pile diameter, pile spacing, the internal friction angle of the soil, and the subentry efficiency factors of the pile groups [26]: 


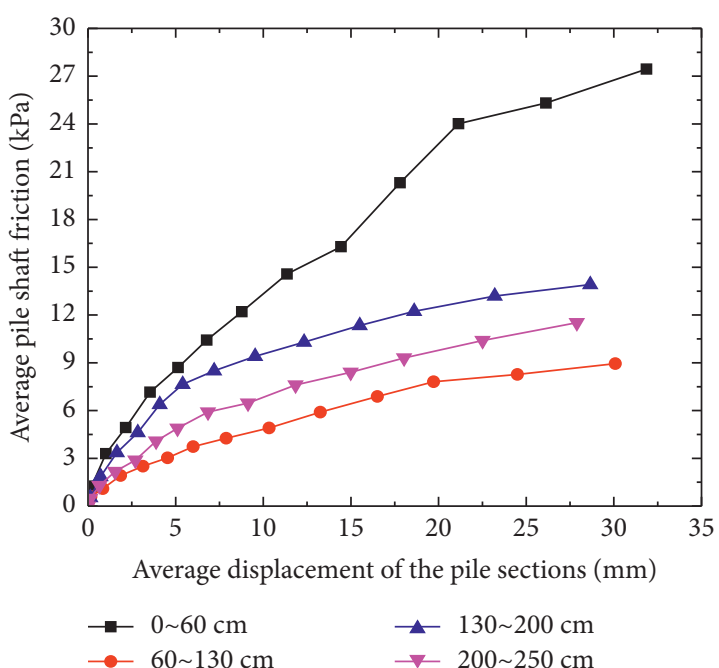

(a)

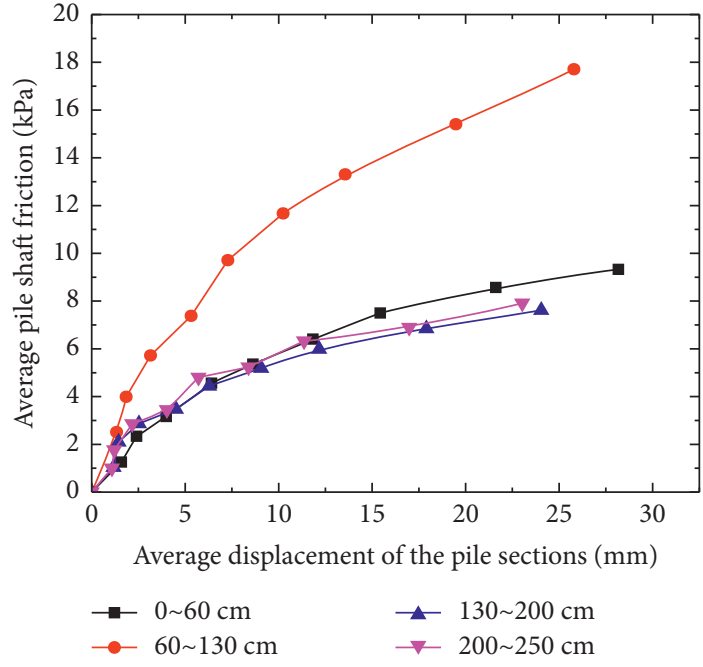

(b)

FIgURE 11: The average pile shaft friction resistance versus the average displacement of the pile sections. (a) LCPF. (b) HCPF.

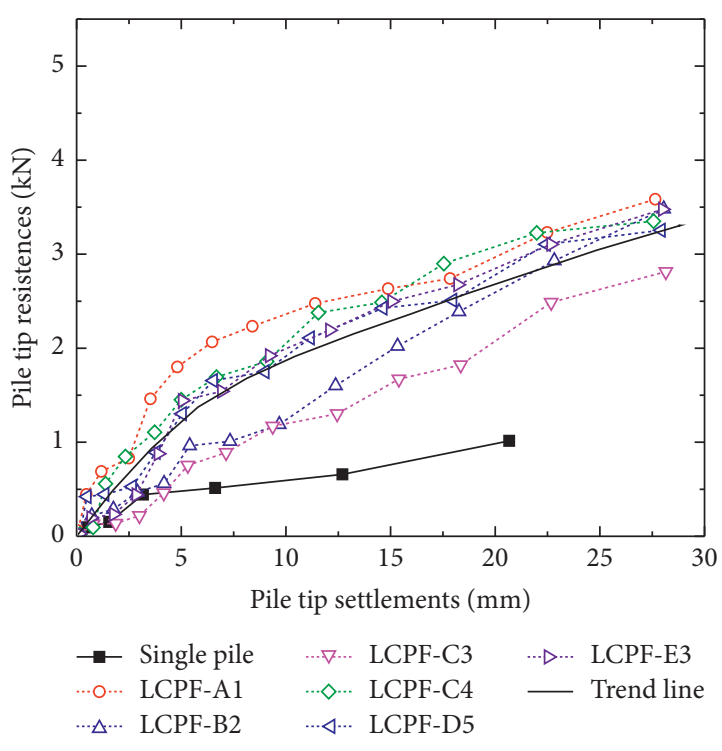

(a)

Figure 12: Pile tip resistance versus the pile tip settlement.

$$
p_{u}=\eta_{s} n Q_{s u}+\eta_{p} n Q_{p u}+\eta_{c} A f_{c k}
$$

where $Q_{s u}$ and $Q_{p u}$ are the standard values of the ultimate friction resistance and ultimate tip resistance of the pile groups, respectively; $f_{c k}$ is the ultimate bearing capacity of the soil under the caps, which is defined as zero in superlong pile groups with a high cap; $A$ is the area of the soil under the caps (excluding the pile section); $\eta_{s}, \eta_{p}$, and $\eta_{c}$ are the coefficient of the friction resistance, the coefficient of the tip resistance, and the coefficient of the soil resistance under the cap, respectively; and $n$ is the number of single piles in superlong pile groups.

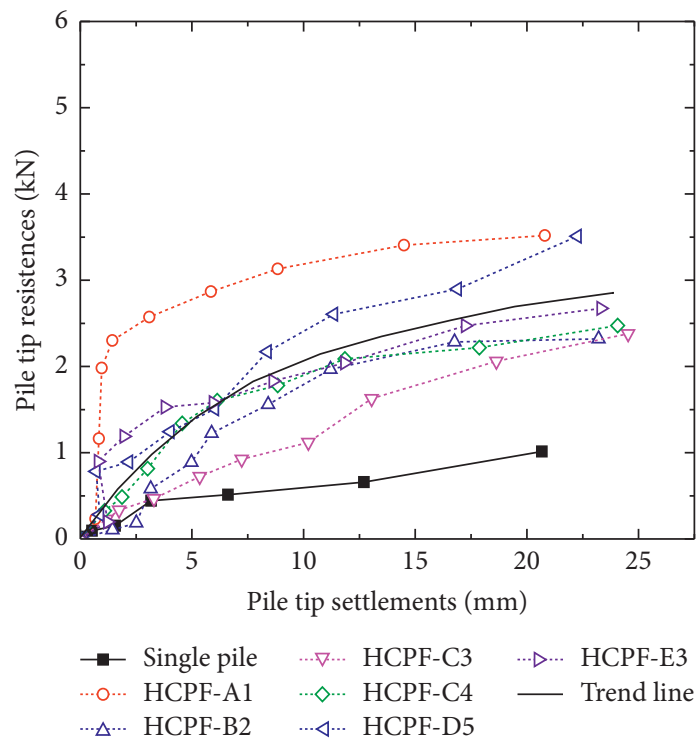

(b)

In addition, in the $\mathrm{HCPF}$, the pile friction resistance provides the main bearing capacity. Therefore, the average coefficient of the friction resistance is used to replace the coefficients of the friction resistance and tip resistance:

$$
p_{u}=\eta_{s p} n Q_{u}
$$

where $Q_{u}$ is the ultimate bearing capacity of a single pile and $\eta_{s p}$ is the average value of the coefficients of the friction resistance and end resistance of the group piles.

In the LCPF, the upper load is borne by the pile and cap and part of the load is borne by the soil between the piles. Meanwhile, each pile in the pile group interacts with the soil 
under the cap at the contact surface. This interaction can generate stress superposition on the upper part of the pile, increasing the shaft friction resistance of the upper part of the pile and improving the overall bearing capacity of the pile group. Therefore, we consider the influence of the load sharing by the pile cap in the LCPF and introduce the coefficients of the cap $\left(C_{s}\right.$ and $\left.C_{p}\right)$ to calculate the bearing capacity of the LCPF:

$$
\begin{aligned}
& p_{u}=C_{s} C_{p} \eta_{s p} n Q_{s u}+\eta_{c} A f_{c k} \\
& C_{s}=1+0.1 \frac{S_{a}}{d}-0.8 \\
& C_{p}=1+0.1 \frac{S_{a}}{d} \sqrt{\frac{B_{c}}{L}}
\end{aligned}
$$

where $f_{c k}$ is the standard value of the ultimate bearing capacity of the soil under the cap, which is obtained from a static load test; $S_{a}$ is the pile distance; $d$ is the diameter of the pile; $B_{c}$ is the width of the cap; $h$ is the depth of the pile in the soil; and $n$ is the number of single piles in superlong pile groups.
4.2. Average Coefficient of the Pile Group. We make the following assumptions for simplification: (1) the load of the cap is evenly distributed, and the tip resistance of the piles is ignored, resulting in a pure friction pile; (2) the lateral friction of the pile has a triangular distribution along the length of the pile; (3) the stress on the side and top of the pile is diffused according to the Mindlin stress solution; and (4) the foundation stress has a parabolic distribution at the plane of the pile tip.

According to assumption (3), the distance from any point in the soil to the pile axis is $r$ and the distance from the ground surface is $z$. The vertical stress at this point can be expressed as

$$
\sigma=\frac{N}{h^{2}} K_{r},
$$

where $N$ is the vertical load on the pile top, $h$ is the depth of the pile in the soil, and $k_{r}$ represents the stress coefficients based on assumption (2), which is calculated as [25]

$$
K_{z z}=\frac{1}{4 \pi(1-v)}\left[\begin{array}{c}
\frac{-2 v(2-v)}{A}+\frac{2(2-v)(4-m)-2(1-2 v)(m / n)^{2}(m-n)}{B} \\
+\frac{4 v m n^{2}+4 m^{2}-15 n^{2} m-2(5+2 v)(m / n)^{2}}{A^{3}} \\
+\frac{(m+1)^{3}+(m+1)^{3}}{B^{3}} \\
+\frac{2(7-2 v) m n^{2}-6 m^{3}+2(5+2 v)(m / n)^{2} m^{3}}{F^{3}} \\
+2(2-v) \log _{e}(A+m-1 / F+m \times B+m-1 / F+m)
\end{array}\right]
$$

where $r$ is the distance from any point in the soil to the pile axis; $z$ is the distance from the ground surface; $F^{2}=n^{2}+m^{2}$;
$A^{2}=n^{2}+(m-1)^{2} ; B^{2}=n^{2}+(m+1)^{2} ; n=r / h ; m=z / h ;$ and $v$ is the average Poisson's ratio of all soil layers. 
TABLE 4: Calculated and measured results.

\begin{tabular}{|c|c|c|c|c|}
\hline \multirow{2}{*}{ Pile type } & \multicolumn{2}{|c|}{$\eta_{s p}$} & \multicolumn{2}{|c|}{$P_{u}$} \\
\hline & Measured value & Calculated value & Measured value & Calculated value \\
\hline Single pile & - & - & 4 & - \\
\hline $5 * 5 \mathrm{HCPF}$ & 1.60 & 1.623 & 160 & 162.33 \\
\hline $5 * 5 \mathrm{LCPF}$ & 2.20 & 2.45 & 230 & 241.79 \\
\hline Pile cap & 0.277 & 0.1874 & 18.24 & 22.43 \\
\hline
\end{tabular}

In this test, when $m>1.0$, the above formula can be simplified at the position of the pile axis as follows:

$$
K_{r}=\frac{1}{4 \pi 1-v}\left[\begin{array}{c}
2-\frac{22-v \mathrm{~m}}{m-1}+\frac{6(2-v) m}{(m+1)} \\
-\frac{2(7-2 v) m^{2}}{(m+1)^{2}}+\frac{4 m^{2}}{(m+1)^{3}} \\
-2(2-v) \log _{e}\left(\frac{m^{2}-1}{m^{2}}\right)
\end{array}\right] .
$$

In this paper [27], it is suggested that the vertical stress at the pile end should be replaced by 10 points below the pile end, i.e., the calculation point ( $L$ is the length of the pile) is used to describe the vertical stress at the pile tip. This approach minimizes the influence of the stress concentration below the plane of the pile end.

For a rectangular arrangement of the pile groups $(a \times b)$, the longitudinal pile distance is $S_{1}$, the transverse pile distance is $S_{2}$, and the oblique distance is $S_{3}$. Between the two piles, due to the influence of the vertical stress caused by the reverse force of the pile side friction, the tip of the single pile is affected by the vertical stress $\sigma_{s}$ as of the adjacent pile, while the maximum vertical stress of the single pile itself at the tip of the pile is $\sigma_{\max }$. The discount rate of the two piles is $A_{S}$. Combined with Euation (7), it is not difficult to deduce the following equation:

$$
A_{S}=\frac{\sigma_{s}}{\sigma_{\max }}=\frac{K_{s}}{K s_{0}} .
$$

One of the piles is most affected by the vertical stress of the 8 adjacent piles, and the maximum reduction rate is $2 A s_{1}+2 A s_{2}+4 A s_{3}$; the side piles are affected by the vertical stress of 5 piles, whose reduction rates are $2 A s_{1}+A s_{2}+2 A s_{3}$ and $A s_{1}+2 A s_{2}+2 A s_{3}$; the reduction rate of the corner pile is affected by the vertical stress of 3 piles, whose reduction rate is $A s_{1}+A s_{2}+A s_{3}$. Thus, the average reduction rate [28] is as follows:

$\overline{A s}=\frac{\left(2 A s_{1}+2 A s_{2}+4 A s_{3}\right)(a b-2 a-2 b+4)}{a b}+\frac{\left(2 A s_{1}+A s_{2}+2 A s_{3}\right)(2 a-4)}{a b}+\frac{\left(A s_{1}+2 A s_{2}+2 A s_{3}\right)(2 b-4)+4\left(A s_{1}+A s_{2}+A s_{3}\right)}{a b}$,

where

$$
\begin{aligned}
& A_{S_{1}}=\frac{K_{S_{1}}}{K_{S_{\max }}} \\
& A_{S_{2}}=\frac{K_{S_{2}}}{K_{S_{\max }}} \\
& A_{S_{3}}=\frac{K_{S_{3}}}{K_{S_{\max }}} .
\end{aligned}
$$

$$
\begin{aligned}
\eta_{c} & =\eta_{c}^{i n}-\frac{A_{c}^{i n}}{A_{c}}+\eta_{c}^{e x} \frac{A_{c}^{e x}}{A_{c}}, \\
\eta_{c}^{i n} & =0.08 \frac{S_{a}}{d}\left(\frac{B_{c}}{L}\right)^{1 / 2}, \\
\eta_{c}^{e x} & =\frac{1}{8}\left(\frac{S_{a}}{d}+2\right),
\end{aligned}
$$

The average coefficient of the lateral resistance of the pile groups is as follows:

$$
\eta_{s}=\frac{1}{1+\overline{A s}}
$$

4.3. The Coefficient of the Pile Cap. The coefficient of the pile cap depends on the distance between the piles, the ratio of the cap width to the pile length, the arrangement of the pile groups, and other factors [29]. When the foundation piles are arranged in a rectangle, the calculation formula is as follows:

where $\eta_{c}$ is the coefficient of the pile group of the soil resistance under the cap; $\eta^{\text {in }}$ and $\eta^{\text {ex }}$ are the pile group coefficients of the soil resistance in the inner and outer soil layers under the cap, respectively; $A_{c}^{i n}, A_{c}^{e x}$, and $A_{c}$ are the areas of the inner layer, outer layer, and entire area under the cap, respectively; $S_{a} / d$ is the ratio of the center-to-center distance to the pile diameter; and $B / l$ is the ratio of the cap width to the pile length.

4.4. Applications. As shown in Table 4, a good agreement is obtained between the calculated and measured results, indicating that the proposed method is applicable to engineering practice. 
The difference between the calculated and measured vertical bearing capacities of the HCPF and LCFP is $1.43 \%$ and $4.88 \%$, respectively. These results demonstrated the high accuracy and reliability of the proposed theoretical calculation method.

\section{Conclusion}

Indoor tests were conducted of single pile and superlong pile groups in saturated silty sand to investigate their bearing behavior under vertical loads. The following conclusions were obtained:

(1) The Q-S curve of the superlong pile groups exhibited a decreasing trend. The ultimate bearing capacity and settlement of the superlong pile groups were significantly different for different cap heights. At the same loading level, the settlement of the foundation piles of the LCPF was smaller than that of the HCPF.

(2) Under a vertical load, the axial force of the foundation piles decreased gradually from the top of the pile to the end, and the axial force of the corner pile, the side pile, and the middle pile decreased consistently in the process of attenuation. In addition, due to the pile group effect, the axial forces were similar for the corner pile and side pile but that of the middle pile was higher.

(3) Under a vertical load, the distribution of the lateral friction of the HCPF was significantly different from that of the LCPF, and the friction resistance of the pile body was different at different depths. Under the ultimate load, the skin friction resistance was relatively low at greater depth due to less relative displacement between the piles and the soil. The pilesoil relative displacement, which can mobilize the ultimate shaft capacity, is, on average, $3 \%$ of the pile diameter in silty sand.

(4) The pile tip resistance of the foundation piles in the superlong pile groups was significantly greater than that of the single pile, and the difference between the pile types increased with increasing pile tip displacement. A significant difference in the pile tip resistance was observed between the HCPF and LCPF.

(5) Under the ultimate load, the load sharing ratio of the pile side resistance of the two types of pile group foundations was about $60 \%$ of the total load. The load sharing ratio at the pile tip of the $\mathrm{HCPF}$ was $40 \%$, and that of the LCPF was $33 \%$. The load borne by the foundation soil under the soil of the LCPF was reduced from about $15 \%$ in the initial loading stage to about $7 \%$, indicating that the foundation soil was deformed after reaching the ultimate bearing capacity. As a result, the load borne by the soil under cap eventually stabilized at $50 \%$ of the ultimate bearing capacity.

(6) An equation was proposed to calculate the ultimate bearing capacity of superlong pile groups in a silt stratum based on the principle of stress superposition. The calculated ultimate bearing capacity was similar to the measured value, with a maximum error of only $4.88 \%$. The applicability of the proposed equation was verified; it provides a reference for calculating the bearing capacity of superlong pile groups.

\section{Data Availability}

The excel data of field tests used to support the findings of this study are available from the first author or the corresponding author upon request.

\section{Conflicts of Interest}

The authors declare that there are no conflicts of interest regarding the publication of this paper.

\section{Acknowledgments}

The authors are thankful to Zhengzhou University for giving space and funding to carry out the research work. This research was funded by a grant from the National Natural Science Foundation of China (51508522).

\section{References}

[1] X. F. Chen, The Theory and Building Cases of Settlement Computation, China Science Press, Beijing, China, (in Chinese), 2005.

[2] Z. M. Zhang, Q. Q. Zhang, G. X. Zhang, and M. F Shi, "Large tonnage tests on super-long piles in soft soil area," Chinese Journal of Geotechnical Engineering, vol. 33, no. 4, pp. 535543, 2011, (in Chinese).

[3] Q. Zhang, Z. Zhang, F. Yu, and J. Liu, "Field performance of long bored piles within piled rafts," Proceedings of the Institution of Civil Engineers - Geotechnical Engineering, vol. 163, no. 6, pp. 293-305, 2010.

[4] X.-j. Zou and M.-h. Zhao, "Axial bearing behavior of superlong piles in deep soft clay over stiff layers," Journal of Central South University, vol. 20, no. 7, pp. 2008-2016, 2013.

[5] X Xu, X Wang, C Cai, and W Yao, "Improved calculation method of super-long pile in deep soft soil area," International Journal of Geomechanics, vol. 18, no. 10, 2018.

[6] W. H. Zhong, M. L. Shi, and S. Y. Liu, "Load transfer performance of overlength piles," Rock and Soil Mechanics, vol. 26, no. 2, pp. 307-318, 2005, (in Chinese).

[7] Q. Zhang, S. C. Li, Q. Q. Zhang, and L Li-ping, "Field and theoretical study of the response of super-long bored pile subjected to compressive load," Marine Georesources \& Geotechnology, vol. 34, no. 1, pp. 71-78, 2016.

[8] J. J. Wang, J. G. Zhu, and S. Wei, "Numerical simulation of behaviour of over-length piles with different base stratum," Rock and Soil Mechanics, vol. 26, no. 2, pp. 328-331, 2005, (in Chinese).

[9] R. Gao, Y. Zeng, and B. Zhu, "Centrifuge model testing on super-long rock-socketed bored piles under vertical loading," Geomechanics and Geoengineering, vol. 6, no. 1, pp. 21-29, 2011.

[10] W.-J. Yao, W.-X. Yin, J. Chen, and Y.-Z. Qiu, "Numerical simulation of a super-long pile group under both vertical and 
lateral loads," Advances in Structural Engineering, vol. 13, no. 6, pp. 1139-1151, 2010.

[11] S.-J. Feng, S.-F. Lu, and Z.-M. Shi, "Field investigations of two super-long steel pipe piles in offshore areas," Marine Georesources \& Geotechnology, vol. 34, no. 6, pp. 559-570, 2016.

[12] C. Wang, S. Lin, and X. H. Li, "Model test study of super-long pile groups," Rock and Soil Mechanics, vol. 28, no. S0, pp. 74-78, 2007, (in Chinese).

[13] S. F. Zhou and H. Q. Kuang, "Model tests on vertical bearing capacity of super-long pile groups in clay," Chinese Journal of Geotechnical Engineering, vol. 31, no. 9, pp. 1472-1475, 2009, (in Chinese).

[14] J. D. Li, X. Wang, Y. J. Yan, B. Liu, S. Li, and Z. Li, "Model test for bearing behavior of large diameter and super long pile group in large thickness loess site," Journal of Engineering Geology, vol. 26, no. 6, pp. 1708-1714, 2018, (in Chinese).

[15] M. Y. Fattah, M. A. Yousif, S. M. K. Al-Tameemi, and Y Mohammed, "Effect of pile group geometry on bearing capacity of piled raft foundations," Structural Engineering \& Mechanics, vol. 54, no. 5, pp. 829-853, 2015.

[16] R. R. Al-Omari, M. Y. Fattah, and A. M. Kallawi, "Laboratory study on load carrying capacity of pile group in unsaturated clay," Arabian Journal for Science and Engineering, vol. 44, no. 5, pp. 4613-4627, 2018.

[17] M. Y. Fattah, R. R. Al-Omari, and A. M. Kallawi, "Model studies on load sharing for shaft and tip of pile groups in saturated and unsaturated soils," Geotechnical \& Geological Engineering, vol. 38, no. 4, pp. 4227-4242, 2020.

[18] Y. S. Deng, J. Q. Zheng, C. Z. Wan, and S. H. He, "Calculation for Settlement of High Cap Extra-long Large Diameter Pile Groups," Applied Mechanics and Materials, vol. 178, no. 181, pp. 2171-2174, 2012.

[19] C. W. W. Ng, H. G. Poulos, V. S. H. Chan, S. S. Y. Lam, and G. C. Y. Chan, "Effects of tip location and shielding on piles in consolidating ground," Journal of Geotechnical and Geoenvironmental Engineering, vol. 134, no. 9, pp. 1245-1260, 2008.

[20] Y. Hong, B. He, L. Z. Wang, Z. Wang, C. W. W. Ng, and D. Mašín, "Cyclic lateral response and failure mechanisms of semi-rigid pile in soft clay: centrifuge tests and numerical modelling," Canadian Geotechnical Journal, vol. 54, no. 6, pp. 806-824, 2017.

[21] B. Zhu, K. Wen, T. Li, L. Wang, and D. Kong, "Experimental study on lateral pile-soil interaction of offshore tetrapod piled jacket foundations in sand," Canadian Geotechnical Journal, vol. 56, no. 11, pp. 1680-1689, 2019.

[22] J. L. Liu and Z. L. Yuan, "Cap-pile-soil interaction bored pile groups in silt and calculation on bearing capacity," Chinese Journal of Geotechnical Engineering, vol. 9, no. 6, pp. 1-15, 1987, (in Chinese).

[23] G. L. Dai, Y. X. Dai, and Y. Z. Liu, "Study of pile group effect coefficient for super-long bored piles," China Civil Engineering Journal, vol. 44, no. 10, pp. 107-112, 2011, (in Chinese).

[24] G. Q. Kong, H. W. Gu, and L. D. Zhou, "Study of group effects efficiency of belled wedge pile groups with low cap," Rock and Soil Mechanics, vol. 37, no. 2, pp. 461-468, 2016, (in Chinese).

[25] J. D. Geddes, "Stresses in foundation soils due to vertical subsurface loading," Géotechnique, vol. 16, no. 3, pp. 231-255, 1966.

[26] Compilation Committee of Pile Foundation Engineering Manual, Pile Foundation Engineering Manual, China Architecture and Building Press, Beijing, China, (in Chinese), 1995.
[27] The Professional Standards Compilation Group of People's Republic of China, JGJ 94-2008 Technical Code for Building Pile Foundations, China Architecture and Building Press, Beijing, China, (in Chinese), 2008.

[28] M. Chen, Study on Pile Group Effect of Bridge Pile Foundation Based on Stress Superposition Principle, Chang'an University, Xi'an, China, (in Chinese), 2019.

[29] J. L. Liu, "Group effects and some problems on the concept design of pile group foundation under vertical load," China Civil Engineering Journal, vol. 37, no. 1, pp. 78-83, 2004, (in Chinese). 